\title{
The Structure of Marine Fish marketing in Kenya: The Case of Malindi and Kilifi Districts
}

\author{
Andrew Wamukota \\ Kenya Sea Turtle Conservation Committee, PO Box 58-80122, Mombasa, Kenya .
}

Keywords: Fish marketing, marketing channel, market structure, constraints.

\begin{abstract}
In Kenya, the marine sub-sector, though a significant source of livelihood and employment, remains small in terms of contribution to the national economy. This study, undertaken between October 2000 and March 2001, examines and provides an insight into the structure of marine fish marketing as well as identifies constraints in the marketing system in Malindi and Kilifi districts. Through the use of questionnaires, informal interviews, observation and review of secondary information, two main marketing channels, differentiated by gender and value added practices (mainly frying), were identified. Factors determining the choice of a marketing channel were found to be ownership of storage facilities, profit margin and time to selling location, while constraints in the marketing system related to infrastructure and socio-economic factors. The study recommends investment in fish storage facilities as a way of strengthening the marine fish marketing structure by improving the bargaining power of traders and increasing profit margins.
\end{abstract}

\section{INTRODUCTION}

Fish has been the world's major commodity traded for more than a thousand years and has influenced living conditions for just as long (Kaplinsky 2000). Trade in seafood products has continued to increase over the past two decades from an average of $35 \%$ between 1984 and 1994 to an annual average of $37 \%$ of world catch between 1995 and 2003 (Gudmundsson et al. 2006).

In 2003, fish was a source of protein for about 2.6 billion people and constituted about $16 \%$ of animal protein (FAO, 2004). The first level sale value of fish catch amounted to around US\$ 78 billion, while about 50 million tonnes of fish and fishery products entered the global trade, with an estimated value of US $\$ 58.2$ billion (FAO, 2004). Employment in capture fisheries has grown at a rate of $2.6 \%$ since 1990 supporting livelihoods of 100-200 million people directly or indirectly, ninety percent of them living in developing countries (FAO, 2004).

Changes in the institutional framework, and particularly the introduction of 200 mile Exclusive Economic Zones (EEZs), have given coastal nations control over most fish stocks (Munro 1996), thereby creating new opportunities and challenges for fishermen and the seafood industry all over the world.

In Kenya, the fisheries' resources comprise the freshwater (lakes, rivers and dams) and marine sub-sectors. However, Lake Victoria 
is the main source of fish production in the country as it contributes over $90 \%$ of the total Kenyan fish landings (Karuga and Abila 2007). The rest is shared among other fresh water sources and the marine sub-sectors. The fisheries' contribution to the country's economy is through employment creation, generation of income and foreign exchange earnings.

In terms of employment the fisheries department estimated in 1995 that 798,000 Kenyans were, directly or indirectly, supported by the sector in comparison to 720,000 in 1993. In the same year (1995), the department estimated that there were 34,000 fishermen with an estimated 238,000 dependants and about 526,000 other people engaged in the provision of support and ancillary services such as trade in fish inputs, fish handling, processing and marketing.

The value of fish landed in Kenya in 1996, was Ksh. 6,667 million, increasing to Ksh. 7,668 million in 2002 (Gitonga and Achoki 2003). The industry is believed to be an increasingly important source of food even to people living far away from the fish producing areas (Ikiara, 1999). The fishing industry is the lifeline for the Kenyan riparian and coastal communities in terms of its contribution to employment and income.

\section{Fish marketing}

Fish marketing in Kenya has a long history (see Adhiambo, 1988, Ogutu, 1988). The structure of some fish market has been documented (Abila 1995; Kasirye-Alemu 1988; Abila and Jansen 1997: Karuga and Abila 2007) although most accounts relate to the fresh water fishery. The structure of marine fish marketing in Kenya can best be understood from the forces that define it, starting from fishing itself.

Fishing is carried out at two distinct levels, artisanal and industrial and to some extent ornamental and sport fishing. Artisanal fishing is the most commonly practiced by artisanal fishers who form an estimated $99.5 \%$ of the fisher folk commonly using simple wooden fishing vessels (Karuga and Abila 2007). The estimated 10,154 fishermen (Kamau et al., 2009) operate an approximately 2,400 non-motorized craft of various types. The most common being the dug-out canoe (hori) which account for about $58 \%$ of all artisanal marine fishing vessels in the coast region, followed by the wind propelled sail boats (mashua) which account for nearly $22 \%$. Only about $7.5 \%$ of the artisanal subsector boats are motorized. Karuga and Abila (2007) estimates that 95\% of the fishing boats and gears are mostly owned by boat owners who in most cases are also fish dealers in that they undertake the functions of wholesaling, retailing or both. Only a few boats and mostly dugout canoes are actually owned by fishermen themselves.

Reliable data and information regarding the contribution of marine fisheries is scanty (Karuga and Abila 2007). However, it is estimated that the subsector accounts for around $4 \%$ of the total national catch and employs around 10,000 fishers (Department Fisheries, 2006). Although it remains small (Kamau et al, 2009), the marine subsector is very important to Kenya's economy as a source of livelihood, employment and foreign exchange earnings. The subsector contributes about $0.3 \%$ of Kenya's GDP, while over 10,000 people are estimated to derive their livelihood directly from fishing activities (Kamau et al. 2009) and an estimated 200,000 work in ancillary activities- trade, boat building, engine repair and gear sales (Mwakilenge, 1996). Though large, these figures are only estimates as there is little information and data to confirm their reliability as different sources give dissimilar information.

Nevertheless, information available indicates that the artisanal fisheries alone, which is estimated to handle an estimated 7,000 MT of fish annually is larger than the industrial fishery (Karuga and Abila 2007). Data on fish (or prawns) landed by industrial fishing companies is not 
well documented, making it difficult to provide sufficient insights into the relative importance of this channel in terms of the volume of business handled, employment and earnings. The contribution of the marine fishery to livelihoods, employment and foreign exchange cannot be underestimated, yet this has happened against the backdrop of various structural constraints (Ochiewo 2004, Kamau et al, 2009) that resulted in the fishery remaining relatively small. The sub sector constraints, also termed as driving forces, include heavy reliance on coastal markets where about $95 \%$ of marine fish landed along the Kenyan coast is consumed locally (Karuga and Abila, 2007).

The presentation of various constraints relating to marine fishery in Kenya by Ikiara (1999) is useful in providing general theoretical information. So is the identification of subsector channels (Karuga and Abila 2007). However salient features of the market structure at specific sites may not necessarily be captured. This study goes beyond theoretical and anecdotal information regarding marine fish marketing structure to undertake empirical analysis that identifies fish marketing channels, factors that influence the choice of a marketing channel and constraints in Malindi and Kilifi districts.

\section{MATERIALS AND METHODS}

A market survey of fish traders was carried out in Malindi and Kilifi districts between October 2000 and March 2001 at four landing sites (Ngomeni, Mayungu, Uyombo and Takaungu) (Fig. 1). The survey of traders at the market centers was carried out at four market centers in close proximity to the four landing sites. The market centers sampled are Ngomeni, Malindi, Matsangoni and Takaungu (Fig. 1). Most questions related to the situation on the day of the interview although some questions related to the past. A total of 231 traders from all the landing sites and market centers were sampled randomly (Schaeffer and
Mendenhall, 1990) and interviewed. Effort was made to have equal distribution of traders in the landing sites as well as in the market centers sampled. Data collection techniques included structured questionnaires, informal interviews, observation and use of secondary data from published and unpublished reports.

\section{Data Analysis}

Factors determining the choice of a fish marketing channel were analyzed using a logit model. From the dichotomous value of the dependent variable the logistic analysis estimates the probability that, given the independent variables, an event will or will not occur (Dijkstra, 1997). If the predicted probability is greater than 0.5 the prediction is "yes", otherwise the prediction is "no" (Hair et al., 1995). The logit model estimated (as depicted in (i)) was adapted from Dijkstra (1997) and modified to suit this study.

Thus

$L=\alpha_{0}+\beta_{i} x$ (i)

where $\mathrm{L}$ is the logit symbol and adopts a dichotomous value 1 if channel 2 for processed fish and 0 if channel 3 for fresh fish. The $x i$, are coefficients of the independent variables. They refer to a comparison of the probability of the event occurring with the probability of it not occurring. The probability of an event occurring is calculated as shown in equation (i). Accordingly, individual “i” will make a certain choice, given the knowledge of xi. A positive coefficient increases the probability that the event will occur and a negative one decreases it (Dijkstra, 1997). The variables estimated are as shown in Table 1. The goodness of fit of the model was assessed by means of the model chisquare at 0.01 and 0.05 significant levels. Any variable exceeding 0.05 significance level was considered insignificant. Chi-square tests the null hypothesis that the coefficients for all the terms in the model except the constant are zero. If the null hypothesis is rejected $(p<0.05)$ the model is meaningful (Norusis, 1990). 


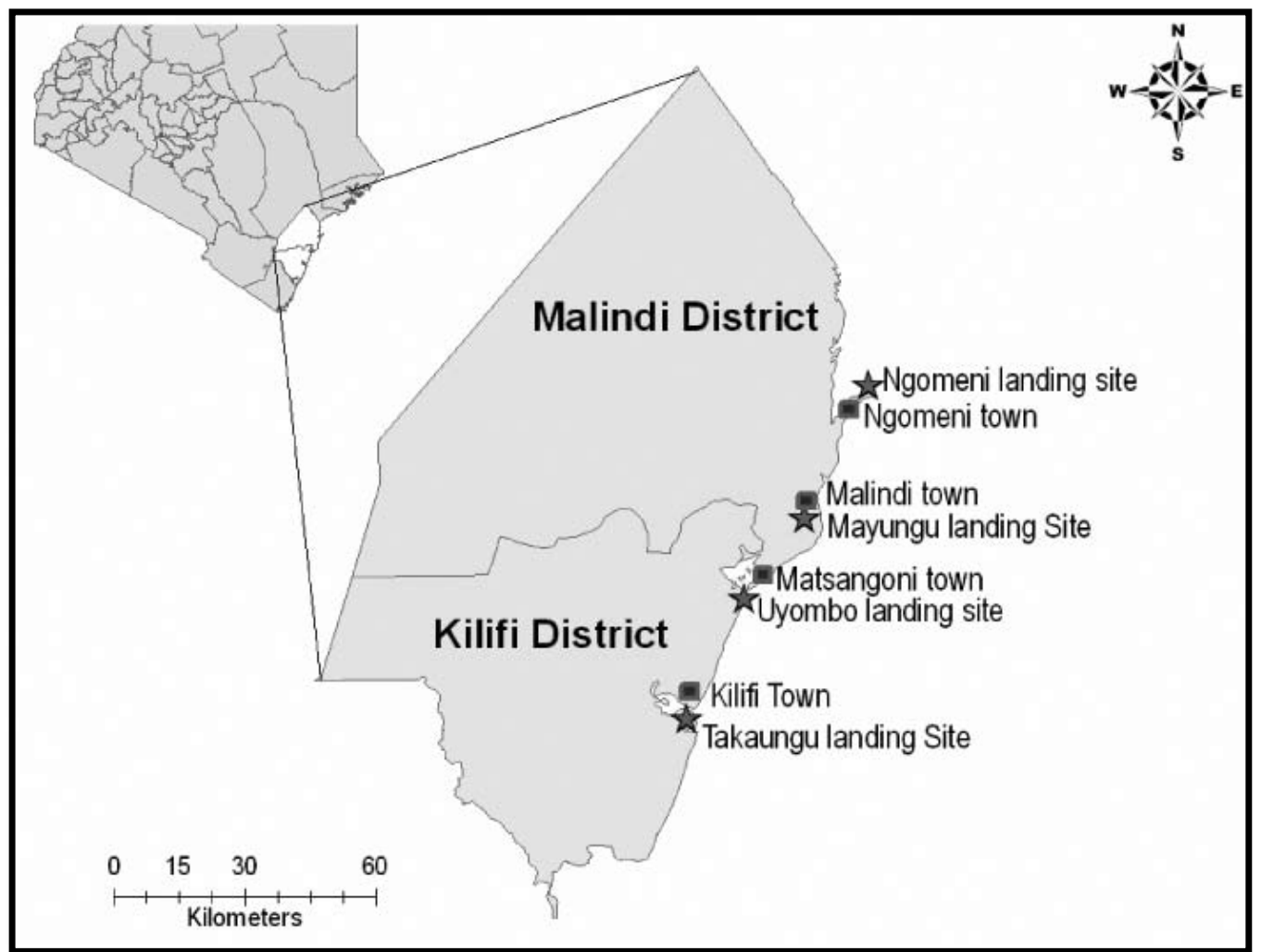

Fig. 1. Map showing the study area

For all the regressors included in the model, $\mathrm{R}^{2}$ values for the auxiliary regressions ranged from 0.073 to 0.70 . It was therefore concluded that multicollinearity was not severe. Results were checked for extreme cases, correlations between independent variables using auxiliary regressions and heteroscedasticity (a condition when the variance depends on one or more explanatory variable) using the GoldfeldQuandt test (Haddad et al., 1995).

\section{Constraints in the fish marketing system}

The demand function was analysed using the consumer theory of demand and supply (Varian, 1990; Lipsey, 1995) adapted from Deaton and Muellbauer (1980) taking into account the equality of demand and supply assumption (equation (ii)).
Thus

$S i=\alpha i+\beta X i+\Sigma \gamma i j P j$

where $S i=$ the quantity of fish marketed and $X i, \gamma i j, P j=$ Independent variables.

The estimated equation whose variables are presented in Table 1 was of the form shown in (iii) below:

Qd $($ NLQAAFS $)=$ OFSF, NLHHS, Educ, NLSPFS, SEX, NLTTSPS .... (iii)

Since the application of ordinary least squares (OLS) to a system of simultaneous equation yields biased and inconsistent estimates, the two stage least squares (2SLS) method was used to estimate parameters of the model. The 2SLS aims to eliminate the simultaneous equation bias, is appropriate for the estimation of overidentified equations and has the advantage of simplicity in conception and computations (Koutsoyiannis, (1977). The overall strength of the model was expressed by the adjusted $\mathrm{R}^{2}$. 
Table 1. Variables used in models to determine 1: factors determining the choice of marketing channel and 2: constraints in the fish marketing system

\begin{tabular}{lll}
\hline 1. Factors determining the choice of marketing channel & \\
\hline Variable & Symbol & Measurement \\
\hline Form in which the fish is marketed (Dependant) & FTFM & $1=$ own, $0=$ not own \\
Ownership of fish storage or cooling facility & OFSF & $1=$ owns, $0=$ does not own \\
Quantity of fish sold & NlqAAFS & Kilograms \\
Profit margins & NLMARGIN & Kenya shillings \\
Transport time to selling point & TTSP & Hours \\
Quantity of fuel wood used for fish & INVQFUPD & Kilograms \\
processing per day & & \\
\hline 2. Constraints in the fish marketing system & & \\
\hline Quantity of fish sold (Dependant) & NLQAAFS & Kilograms \\
Ownership of fish storage facility & OFSF & $1=$ owns, $0=$ does not own \\
Number of household members & NLHHS & Count \\
Education & Nl educ & Number \\
Selling price of fish & NLSPFS & Kenya shillings \\
Sex & SEX & $1=$ male, $0=$ female \\
Transport time to selling point & NLTTSPS & Hours \\
\hline
\end{tabular}

\section{RESULTS AND DISCUSSIONS}

Marine fish marketing starts at the point where fish is landed, although this process is dependant on the prior activity of fishing itself which to a degree is financed by owners of fishing vessels. It is argued (Karuga and Abila 2007) that $95 \%$ of the fishing boats and gears are mostly owned by boat owners who in most cases are also fish dealers in that they undertake the functions of wholesaling, retailing or both, and that only a few boats and mostly dugout canoes are actually owned by fishermen themselves.

Boat owners finance fishing by providing fishing boats and sometimes fishing gear to fishers. After fish is landed under this arrangement, the proceeds are shared in order of agreed sharing methods (see Karuga and Abila 2007). In some instances, the fisher folks have been reported to pay a rental fee of Ksh 200 and 100 per day for use of sail boat and dugout canoes respectively. In other instances, the boat owner may advance small amounts of the payment to the fishermen with the balance being paid later. Fish sale by the boat owner may be at or away from the landing site. The latter may be direct sale to a fish dealer or sale to retailers at the dealers shop (s), located in the main consumer markets.

Part of the catch is however sold to women who are commonly referred to as mama karangas (women who buy fish and later deep-fry it and sell to household consumers) or to local household consumers. According to a recent survey (Karuga and Abila 2007), the mama karangas control over $95 \%$ of the marine fish retailing function. These actors buy fish from wholesalers (about $80 \%$ of purchase), directly from fishermen or in some places from industrial fishing companies in the form of by-catch. Nearly all of these retailers 
operate from makeshift structures along the main streets and villages. Their main outlets are household consumers/ general public in towns and villages.

Wholesaling is exclusively carried out by larger scale traders, who more often than not own fishing vessels and gears. However, reliable data on the number of dealers or wholesalers is not well known although anecdotal information indicates that majority of them are men. Wholesalers normally deal with between 300-500 kilograms of fish per day while other dealers deal with as little as 50-100 kilograms of fish per day or even less. The main sources of fish for this type of actors include fishers (supplying over 75\%) and middlemen.
The traders interviewed ranged from 19 to 60 years old although the majority fell in the age bracket of between 20 to 29 years. An almost equal number of male and female traders operated at the sampled sites. Although gender was not a limiting factor in fish marketing, female traders focused on small fish of smaller quantities for local sales while men bought and sold the larger quantities of fish. An increase in male traders meant an increase in the quantity of fish traded. Traders from the Mijikenda group were in the majority followed by the Bajuni. Almost $43 \%$ of the traders had primary school education while $30 \%$ did not have any formal education. The majority of the traders were Muslims.

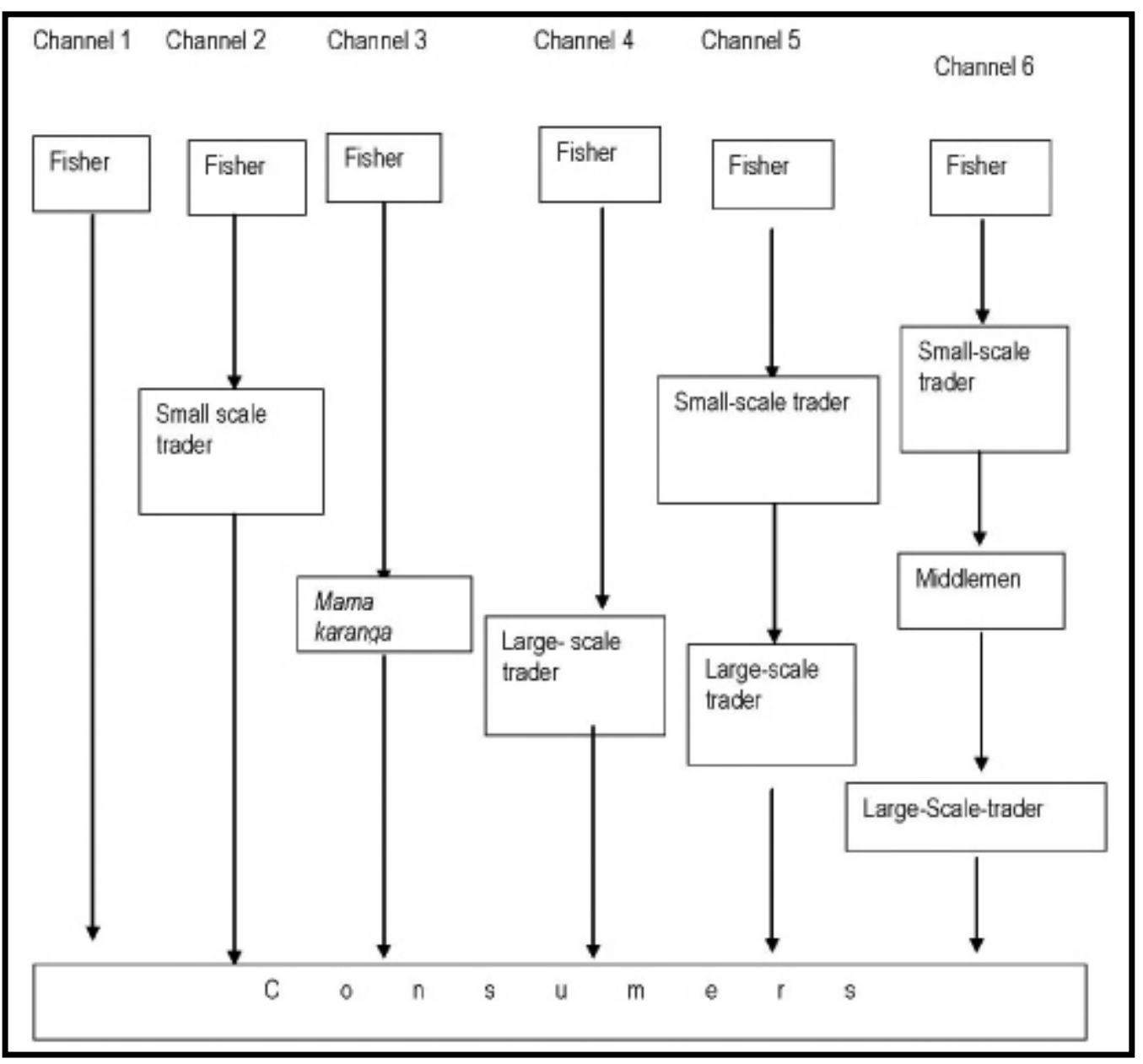

Fig. 2. Main fish marketing channels in Malindi and Kilifi districts 2000/01 
In total, six fish marketing channels (Fig. 2) were identified. The dividing line between the channels was the scale at which the traders operated, the quantity of the product, its extent and value adding practice (processing). These were to a large extent dictated by the volume of fish bought and sold, and ownership of storage as well as transport facilities. It should be noted that despite fish being a highly perishable product, the majority of the 115 landing sites on the whole of the Kenyan coast do not have fish storage facilities (Karuga and Abila 2007). During the survey, only two landing sites had a container sometimes with ice, which were owned by large-scale traders.

Four distinctions of traders were identified. These were mama karangas, small scale traders, middlemen and large scale traders/ wholesalers depending on the quantity of fish traded, the type (fresh or processed) and the scale at which they operated.

Results of this study indicate that fish marketing is done first at the landing sites and then at various markets beyond the landing sites. Fish marketing at the landing sites was mostly done by fishermen who sold fish to traders or to consumers. Mama karanga fish mongers bought fish in small quantities for deep frying and selling at nearby market centers or villages (Table 2). Female traders who bought fish from industrial companies were not encountered. Small-scale traders bought fish from fishermen at the landing site and sold it to middlemen or sometimes to consumers in its fresh form (channels 2 and 6) at the nearby villages, tarmac roads or market centers while middlemen bought the fish from small-scale traders or even fishers and sold to large scale traders or other traders operating retail shops. Some were subcontracted by large scale traders to buy fish on their behalf. In some cases, large-scale traders sold fish to middlemen who operated retail shops or directly to consumers (household and hotels). Large-scale traders on the other hand bought fish in bulk from fishermen, smallscale traders or middlemen. Some large-scale traders owned fishing vessels and therefore visited the landing sites to collect fish landed by their vessels (channel 4) or subcontracted middlemen to buy fish for them. They later sold it to hotels or other traders in Malindi, Mombasa, Kilifi or Nairobi in fresh form. The large scale traders encountered were mostly individuals and not companies and were very few compared to artisanal fishermen who operated on their own.

In general, apart from traders who exclusively processed fish in small quantities by mostly frying before marketing it (mama karangas), other trader categories mainly dealt in comparatively larger quantities of fresh fish. Also the quantities of fish that a particular trader dealt in for instance did not exclusively depend on the trader's financial position but to an extent the amount of fish he/ she could manage to get in a day depending on networks and or contracts and landings. This influenced the scale at which some operated. Considering all these factors, the

Table 2. Fish marketing channels and volumes in Malindi and Kilifi districts 2000/01

\begin{tabular}{lrrrr}
\hline Channel & Number & Volume & $\begin{array}{c}\text { Std. } \\
\text { deviation }\end{array}$ & Mean \\
\hline Fisher $\rightarrow$ small-scale trader $\rightarrow$ consumer & 9 & 331 & 45.6 & 36.7 \\
Fisher $\rightarrow$ fishmonger $\rightarrow$ consumer & 74 & 458 & 5.5 & 6.2 \\
Fisher $\rightarrow$ large-scale trader $\rightarrow$ consumer & 15 & 546 & 24.7 & 36.4 \\
Fisher $\rightarrow$ small-scale trader $\rightarrow$ Large-scale trader $\rightarrow$ consumer & 17 & 566 & 30.76 & 33.3 \\
Fisher $\rightarrow$ small-scale trader $\rightarrow$ middleman $\rightarrow$ Large-scale trader $\rightarrow$ consumer & 25 & 1199 & 35.57 & 48 \\
\hline Total & $\mathbf{1 4 0}$ & $\mathbf{3 0 9 9}$ & $\mathbf{2 8 . 8}$ & $\mathbf{2 2 . 1}$ \\
\hline
\end{tabular}


marketing channels depicted in Fig. 2 can be divided into the two most conspicuous gender differentiated, with women dominating the fish processing/ mostly frying channel and men concentrating on the fresh fish channel.

Although the subsector map presented (Fig. 2) should not be looked at as static, it illustrates the mostly observed marketing channels. The channel that carried the largest volume of fish was the channel fisher $>$ smallscale $>$ trader $>$ middlemen $>$ large-scale traders $>$ consumer (household or restaurants) (Table 2).

Results of the logistic analysis points to ownership of storage facilities as a determinant of the choice of marketing channel. Preliminary results indicated that mama karangas lacked most of the infrastructure including storage facilities (apart from wooden boxes in which they put processed fish for display) and means of transport. Only about $40 \%$ of the traders mostly female traders transported their fish on foot and another $37 \%$ used bicycles. Only three percent of the traders had their own vehicles, which they used to transport fish to various selling locations.
Ownership of fish storage facilities also acted as a constraint (Table 3 ) in the fish marketing system. The lack of fish storage facilities is not limited to the surveyed sites, but are lacking in many parts of the Kenyan coast (Karuga and Abila 2007).

\section{CONCLUSIONS}

Most accounts of fish marketing in Kenya relate to fresh water fishery which contributes over $90 \%$ of fish production in Kenya. Research done so far with regard to marine fisheries marketing points out to the paucity of data and information with regard to some players in the marketing channel. In this study a more specific and site based empirical analysis is undertaken in order to expose salient interactions and processes that define the structure of marine fish marketing in two districts of Malindi and Kilifi, Kenya.

The salient interactions relate to the steps of fish marketing and players involved, with mamakaranga fish tradercategory specializing in processed fish. Very few large-scale traders were encountered in the marketing channel. This trader category influenced financing of fishing by providing fishing boats and gear

Table 3. 2SLS estimates for the constraints in the fish marketing system in Malindi and Kilifi districts 2000/01

\begin{tabular}{lrrrrl}
\hline Variable & B & SE B & Beta & T & Sig T \\
\hline INVQAAFS & -4.280173 & 3.009465 & -.577575 & -1.422 & .1649 \\
OFSF & 1.501086 & .484798 & .663641 & 3.096 & $.0041^{* *}$ \\
NLHHS & .295485 & .156990 & .263706 & 1.882 & $.0692^{*}$ \\
NLEDUC & -.174481 & .366778 & -.072194 & -.476 & .6376 \\
NLSPFS & -.095690 & .278448 & -.049700 & -.344 & .7334 \\
GENDER & .396014 & .371576 & .216152 & 1.066 & .2948 \\
NLTTSPS & .030245 & .062174 & .103802 & .486 & .6301 \\
(Constant) & 2.463717 & 1.339430 & & 1.839 & $.0755^{*}$ \\
\hline
\end{tabular}

* Significant at $10 \%$ significant level,

** significant at $5 \%$ significant level

Dependent variable: NLQLFB, Adjusted R Square=. 47575, Standard Error=. 70170, F = 5.92637, $\mathrm{df}=7$, Sig. $\mathrm{F}=.0002$ 
and sometimes engaged middlemen to buy fish on their behalf. Determinants of choice of marketing channels related to ownership of storage facilities and to some extent time taken to fish selling locations. The ownership of fish storage facilities also acted as a major constraint. Results of this study suggest the need to invest in fish storage and preservation facilities at landing sites.

Acknowledgments - I am grateful to Moi University for offering me a chance to pursue my M. Phil and for enabling me write my thesis of which this paper is part. I particularly thank my supervisors, Professor H. Maritim, Professor W. Yabban, and Professor B.C.C. Wangila who encouraged me all through.

Research grant was provided by the Netherlands and Israel Research Program (NIRP). I am particularly indebted to Professor Jan Hoorweg of the African Study Centre who was instrumental in providing field facilitation and direction during the initial phase of this study. Thanks also to research assistants in the study areas.

\section{REFERENCES}

Abila R.O (1995). Assessment of Fisheries Products Values along Kenya's Export Marketing Chain. Proceedings of the FAO Expert Consultation on Fish Technology, Utilization and Quality Assurance, 14-18th November 2005, Bagamoyo, Tanzania.

Abila, R.O. and E.G. Jansen (1997). "From Local to Global Markets: The Fish Exporting and Fishmeal industries of Lake Victoriastructure, strategies and socio-economic impacts in Kenya". Socio-economics of the Nile perch Fishery of Lake Victoria Project Report No.2. IUCN-EARO. Nairobi.

Adhiambo, W.J.O. (1988). Lake Victoria Fisheries and Fish trade, In Ogutu, G.E.M ed. Artisanal Fisheries of Lake Victoria, Kenya: Options for Management, Production, and Marketing. Sirikon Publishers and IDRC, Nairobi. pp. 63-75.

Deaton A. and John Muellbauer (1980). An Almost Ideal Demand System. The American Economic Review, 70 (3): 312-326.
Department of Fisheries (2006). Marine Waters Frame Survey Report, 2006.

Dijkstra,T. (1997). Trading the fruits of the land. Horticultural marketing channels in Kenya. Ashgate Publishing Ltd. Aldershot.

FAO (2004). The state of the world Fisheries and Aquaculture 2004. FAO. Rome, Italy .

Gitonga, N.K. and Achoki, R. (2003), Fiscal Reforms for Kenya Fisheries: Paper Prepared for FAO Workshop on Fiscal Reforms for Fisheries (Rome, Italy: 13-15 October 2003). Available online at:

http://www.fao.org/docrep/007/y5718e/y5718e04.htm

Gudmundsson, E.; Asche, F.; Nielsen, M. (2006). Revenue distribution through the seafood value chain. FAO Fisheries Circular. No. 1019. Rome, FAO.

Haddad, L., Westbrook M.D., Driscol, D., Payongayong, E., Rozen, J., and Weeks, M. (1995). Strengthening Policy Analysis: Econometric tests using Microcomputer Software. Microcomputer in Policy research 2, IFPRI, Washington D.C.

Hair, J. F., R.E. Anderson, R.L. Tathan and W.C. Black (1995). Multivariate Data Analysis. $4^{\text {th }}$ ed. Prentice Hall. Englewoods Cliffs.

Ikiara, M.M. (1999). Sustainability, Livelihoods, Production and Effort supply in a Declining Fishery. The case of Kenya's Lake Victoria Fisheries. PhD Thesis (unpublished) University of Amsterdam.

Kamau E.C., Wamukota A., and Muthiga N. (2009) Promotion and Management of Marine Fisheries in Kenya In Winter, G (Ed). Towards Sustainable Fisheries Law. Comparative Analysis. IUCN, Gland, Switzerland. xiv $+340 \mathrm{pp}$.

Kaplinsky, R. (2000). Spreading the Gains from Globalisation: What Can Be Learned from Value Chain Analysis? Institute of Development Studies, Working Paper 110, Sussex.

Karuga S. and R. O. Abila (2007). 'Value Chain Market Assessment for Marine Fish Subsector in Kenya's Coast Region'. Consultancy Report for the Coast Development Authority. Coastal Micro-Enterprise Development Program. Mombasa. Kenya. 
Kasirye-Alamu, E. C. (1988). "Fish handling and processing in Artisanal Fisheries of Lake Victoria, Kenya", in Ogutu, G.E.M., (ed.) (1988). Artisanal Fisheries of Lake Victoria, Kenya: Options for management, production and marketing. Proceedings of a workshop held in Kisumu, Kenya

Koutsoyiannis, A. (1977). Theory of Econometrics. The Macmillan Press Ltd.

Lipsey, R.G. (1995). An introduction to positive economics. Oxford University press. New York.

Munro, G.R. (1996). Approaches to the Economics of the Management of High Seas Fishery Resources. In D. V. Gordon and G. R. Munro (1996). Fisheries and Uncertainty: A Precautionary Approach to Resource Management. University of Calgary Press, Calgary.

Mwakilenge, E. (1996). 'Toward Sustainable Development in the Fishing Industry of Coast Province In: Technical Report No. 1. Department of Fisheries, Moi University.
Norusis, M.J. (1990). SPSS Advanced Statistics Student Guide, SPSS Inc.: Chicago.

Ochiewo, J. (2004) Changing fisheries practices and their socioeconomic implications in South Coast Kenya. Ocean \& Coastal Management, 47(7-8): 389-408pp.

Ogutu, M.A (1988). The role of women and cooperatives in Fish marketing in Western Kenya. In Ogutu G.E.M ed. (1988) “Artisanal Fisheries of Lake Victoria, Kenya: Options for management, production and marketing. Proceedings of a workshop held in Kisumu", Kenya. pp.113-117.

Schaeffer, L.R and Mendenhall W., (1990). Elementary survey sampling. $4^{\text {th }}$ Ed., Duxbury press. Belmond.

Varian, H. (1990). Intermediate Microeconomics $2^{\text {nd }}$ edition. W.W.Norton and company Ltd. London pp 1-33. 